\author{
RAMADONA \\ Universitas Katholik Parahyangan \\ archibuana@gmail.com
}

\title{
PERAN PENANGKAL MATAHARI DALAM MENGATASI SILAU PADA DINDING KACA BANGUNAN TINGGI DI IKLIM TROPIS LEMBAP
}

\begin{abstract}
Abstrak: Melihat fenomena yang terjadi di dunia arsitektur saat ini, banyak arsitek profesional menggunakan teori arsitektur yang kurang tepat dalam perencanaannya. Salah satu contohnya teori bangunan tinggi di iklim subtropis diterapkan pada desain bangunan tinggi yang berada di iklim tropis lembap, tentunya hal tersebut akan mengakibatkan dampak yang signifikan di dalam bangunan dan di luar bangunan.

Pada negara beriklim Subtropis penggunaan kaca digunakan untuk penerangan alamiah dan membuat akumulasi panas sehingga membantu beban energi Heater pada musim dingin. Namun apabila dinding kaca atau Curtain Glass diaplikasikan di negara yang beriklim tropis lembap, maka akan mempunyai permasalahan ketidaknyamanan termal di dalam bangunan dan ketidaknyamanan visual pada lingkungan luar bangunan. Fokus penelitian yang dibahas pada tesis ini terbatas hanya pada lingkup ketidaknyamanan visual di luar bangunan serta dampak yang dihasilkannya, yaitu glare atau silau, karena fenomena ini yang sering terlihat pada bangunan bertingkat banyak yang menggunakan curtain glass sebagai fasade .

Metoda penelitian yang digunakan dalam penelitian ini adalah metoda simulasi dengan menggunakan software sketchup sebagai permodelan awal dan autodesk ecotect yang digunakan untuk mensimulasikan bagian fasade yang terkena paparan sinar matahari, sehingga dapat diperoleh hasil dari analisis tersebut. Selain itu metoda penelitian ini merupakan cara tepat, terukur dan mudah untuk dipahami, karena langsung menggunakan permodelan 3 dimensi yang bentuk dan dimensinya serupa dengan objek aslinya.

Dalam penelitian ini digunakan permodelan sun shading yang diaplikasikan pada fasade bangunan terutama curtain glass, yang diharapkan dapat meminimalkan terjadinya faktor glare atau silau pada dinding fasade bangunan. Serta diharapkan peneliti dapat menemukan permodelan sun shading yang tepat untuk bangunan objek studi dalam hal ini dinding fasade bangunan Hotel Ibis Trans Studio Mall Bandung.
\end{abstract}

Kata kunci: silau atau glare, dinding kaca, permodelan sun shading

Abstract: Looking at the phenomenon that occurs in the world of architecture today, many professional architects use the theory of architecture that is less precise in its planning. One example of high-rise building theory in subtropical climates is applied to high-rise building designs in a humid tropical climate, surely it will have significant impacts inside buildings and outside buildings.

In Subtropical temperate countries the use of glass is used for natural lighting and makes heat accumulation thus helping the Heater energy load in winter. But if the glass or Curtain Glass wall is applied in a humid tropical country, it will have problems with thermal discomfort in the building and visual discomfort in the outer environment. The research focus discussed in this thesis is limited only to the scope of visual discomfort outside the building as well as the resulting impact, ie glare or glare, as this phenomenon is often seen in multi-storey buildings that use curtain glass as a fasade.

The research method used in this research is simulation method by using sketchup software as initial modeling and autodesk ecotect which is used to simulate part of facade exposed by sun exposure, so that can be obtained from the analysis. In addition, this research method is the right way, measurable and easy to understand, because it directly uses 3-dimensional modeling of the shape and dimensions similar to the original object.

In this study used sun shading modeling applied to the facade of the building, especially curtain glass, which is expected to minimize the occurrence of glare or glare factor on the building facade wall. And expected researchers can find the right sun shading modeling for building object of study in this case the building facade wall Hotel Ibis Trans Studio Mall Bandung.

Keywords: glare, curtain glass, sun shading modeling 


\section{PENDAHULUAN}

\subsection{Latar Belakang}

Indonesia sebuah negara yang terletak di kawasan Tropis pada lintasan garis Khatulistiwa $6^{\circ}$ lintang Utara dan $11^{\circ}$ lintang Selatan, dianugerahi Tuhan dengan iklim Tropis lembap yang disinari oleh cahaya matahari sepanjang tahun dengan suhu rata-rata $26-28^{0}$ Celcius, bangunan di kawasan Tropis dituntut harus mempunyai desain tata cahaya yang baik, tata udara yang baik serta orientasi bangunan yang benar.

Fenomena yang terjadi di Indonesia banyak bangunan tinggi yang memakai dinding kaca tanpa menggunakan sun shading baik vertical atau horizontal yang dapat mengatasi faktor permasalahan iklim, seperti hujan, radiasi matahari dan glare pada dinding kaca yang berpengaruh terhadap lingkungan sekitar, seperti yang terlihat pada objek studi bangunan hotel Ibis Trans Studio Mall Bandung. Peneliti tertarik untuk meneliti bangunan tersebut karena bangunan tersebut menggunakan fasade dinding curtain glass yang pada saat ini banyak digunakan di negara kita yang beriklim Tropis lembap.

Desain bangunan tinggi yang menggunakan dinding kaca tanpa sun shading sangat baik bila diaplikasikan di daerah yang ber-iklim Sub Tropis, bangunan tersebut berada di daerah yang bertemperatur dingin sehingga bangunannya membutuhkan banyak bidang kaca untuk menyerap sinar dan radiasi matahari ke dalam bangunan, kaca berfungsi untuk menahan akumulasi radiasi panas di dalam bangunan supaya radiasi panas tersebut tidak keluar dari dalam bangunan sehingga ruangan akan selalu hangat pada musim dingin, akumulasi panas tersebut dapat membantu efesiensi pemakaian (heater) di ruangan.

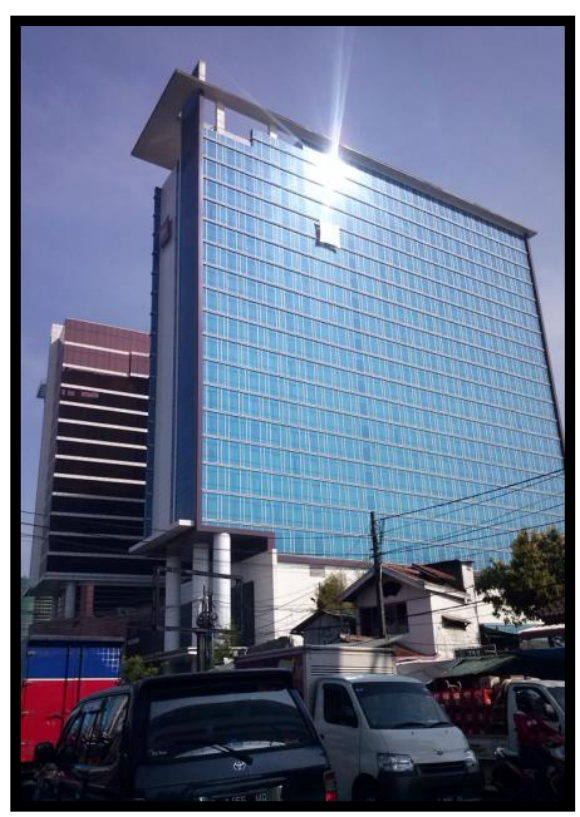

Gambar 1. Hotel Ibis Trans Studio Mall Bandung
Jika bangunan yang menggunakan dinding kaca tanpa sun shading diletakkan di kawasan Tropis lembap di Indonesia, maka yang akan terjadi adalah permasalahan terhadap radiasi panas di dalam bangunan dan ke-tidaknyaman-an visual pada bagian luar bangunan, karena menimbulkan efek glare atau silau pada lingkungannya.

Peneliti memilih hotel Ibis di kawasan Trans Studio Mall Bandung sebagai objek studi penelitian, dikarenakan fenomena silau atau glare yang peneliti alami cukup mengganggu kenyamanan visual, hal tersebut peneliti angkat sebagai issue utama dalam penelitian ini. Fasade bangunan objek studi menggunakan material fasade curtain glass dan dinding alumunium composites panel (ACP) yang mendominasi dinding fasade bangunan tersebut, material fasade teresebut mengakibatkan terjadinya glare atau silau meskipun alasan penggunaan curtain glass pada bangunan ini lebih ditujukan untuk mencapai nilai estetika, mudah dalam perawatan dan konstruksinya.

Dalam penelitian ini peneliti menetapkan 3 kriteria dalam objek penelitian, selain berdasarkan fenomena dan isu yang peneliti alami yaitu sebagai berikut :

1. Bangunan objek studi memiliki orientasi hadap Utara-Selatan.

2. Fokus objek penelitian pada bangunan kaca bertingkat minimal 10 lantai.

3. Kondisi sekitar lingkungan objek studi mempunyai pandangan visual yang bebas tidak terhalang, agar hasil observasi dapat berjalan dengan baik dan akurat.

Peneliti tidak memilih bangunan hotel Trans dalam penelitian ini karena bangunan Hotel Trans merupakan bangunan yang menjadi penghasil efek bayangan atau Shadow Effect 
pada bidang fasade sebelah barat hotel Ibis Bandung, sehingga efek glare atau silau pada bidang fasade hotel Ibis sebelah barat tidak terjadi karena terhalang oleh bangunan Hotel Trans pada saat posisi puncak penyinaran matahari di sore hari mulai dari jam 2 siang hingga jam 5 sore.

Mayoritas penelitian dan jurnal ilmiah lima tahun terakhir lebih banyak terfokus pada kenyamanan termal dan kenyamanan auditory, penelitian mengenai Glare yang dilakukan oleh Ardiyanto (1999) dengan objek studi menara Imperium Jl. HR. Rasuna Said di Jakarta, membuktikan bahwa pada bangunan tinggi tersebut terjadi glare atau silau dengan menggunakan metoda instrumen kamera, sedangkan dalam tesis ini peneliti ingin membuktikan terjadinya glare atau silau pada bangunan tinggi dengan metoda riset simulasi yang dijalankan dengan program Google Sketchup untuk permodelan awal dan Autodesk Ecotect untuk simulasi penyinaran sinar matahari.

\subsection{Isu dan Pertanyaan penelitian}

Latar belakang pemikiran diatas menjadi dasar permasalahan bagi peneliti untuk melakukan penelitian terhadap objek studi bangunan hotel Ibis di kawasan Trans Studio Mall Bandung, untuk itu peneliti merumuskan permasalahan yang akan peneliti uraikan sebagai berikut :

1. Berapa besar intensitas glare atau silau yang terjadi di fasade hotel Ibis Trans Studio Mall Bandung?

2. Bagaimana tipe fasade yang efektif untuk mengatasi glare atau silau, serta mengetahui nilai intensitas glare atau silau yang terjadi dari tiap tipe fasade?

\section{KAJIAN LITERATUR}

\subsection{Kawasan Tropis}

Tropis berasal dari kata Tropikos dalam bahasa Yunani kuno yang artinya garis balik, yang merupakan $40 \%$ bagian dari seluruh permukaan bumi. Garis-garis balik ini adalah garis lintang $23^{\circ} 27^{\prime}$ lintang Utara dan Selatan. Garis lintang Utara $2^{\circ} 27^{\prime}$ adalah garis balik Cancer, posisi matahari pada tanggal 22 Juni adalah tegak lurus garis lintang Selatan $23^{\circ} 27^{\prime}$ dinamakan garis balik Capricorn, dan posisi matahari pada tiap tanggal 23 Desember berada pada posisi tegak lurus garis lintang Utara. Pembagian bumi dengan garis tegak ini tidak

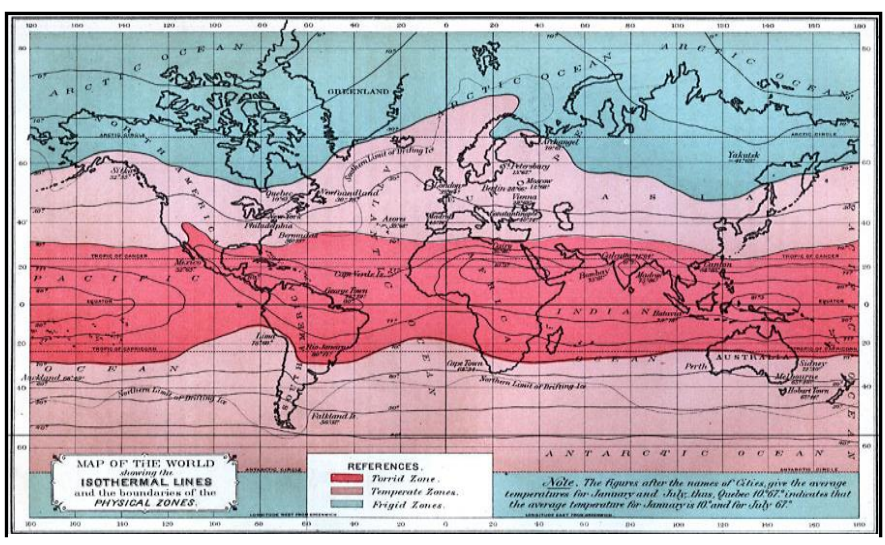

Gambar 2. Peta Kawasan Tropis sumber data: Manual Tropical Housing and Building Keoning Berger. 1973 mempertimbangkan batas-batas daerah iklim yang sebenarnya, oleh karena itu pada masa sekarang ini yang menjadi cakupan daerah Tropis adalah daerah yang terletak antara garis isoterm $20^{\circ} \mathrm{C}$ di sebelah Utara dan Selatan Bumi (Georg Lippsmeier, 1994).

\subsection{Glare atau silau}

Glare adalah efek visual yang dihasilkan dari sinar matahari yang memantul pada bidang datar yang mempunyai sifat refleksi spekular, Sumber glare atau silau bisa berasal dari lampu penerangan atau sinar matahari.

Illuminating Engineering Society of North America (IES) Pengertian Glare atau silau sebagai, "Sensasi yang dihasilkan oleh pencahayaan pada bidang visual yang dapat diterima 


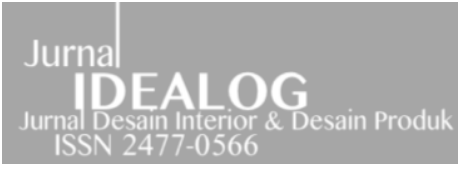

ruang akibat sinar matahari yang masuk berlebih, untuk mengatasi permasalahan tersebut digunakanlah sun shading sebagai buffer pada bukaan atau sebuah bidang fasade.

Perangkat sun shading eksterior sering digunakan dalam desain bangunan kontemporer untuk mengurangi dampak panas atau radiasi matahari serta mencegah silau yang mengganggu kenyamanan visual lingkungan sekitar.

Sun shading merupakan salah satu cara atau strategi dan langkah pertama untuk mencapai kenyamanan termal didalam bangunan, namun untuk mencapai kenyamanan termal yang optimal terdapat beberapa aspek lain yang harus diperhitungkan.

\subsection{Jenis Sun Shading}

Jenis sun shading saat ini sangat beragam terbagi menjadi beberapa jenis pada penelitian yang dilakukan oleh Wall \& Hube (2003). Sun shading dibagi menjadi tiga yaitu sun shading external, interpane dan internal. Berdasarkan hasil analisis ketiga jenis diatas sun shading diatas yang paling baik untuk digunakan di daerah beriklim Tropis lembap seperti Indonesia adalah jenis sun shading external.

Sedangkan menurut Norbert Lechner (2001), sun shading dikelompokkan sebagai berikut, yaitu sun shading tipe horizontal overhang, sunshading tipe vertical fin dan sun shading tipe egg crate (gabungan dari tipe vertical dan horizontal)

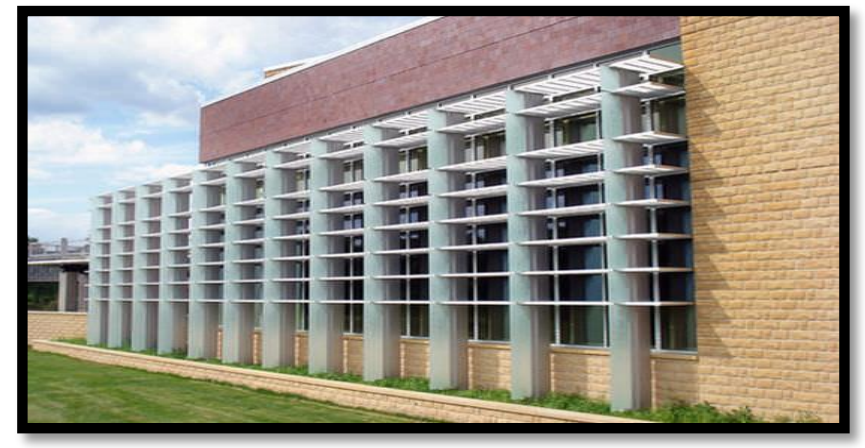

Gambar 9. Sun shading tipe Eggcrate (sumber google)

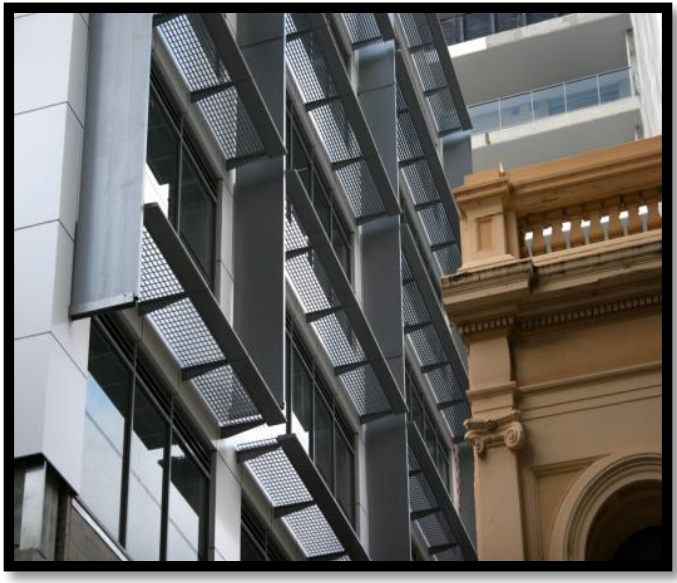

Gambar 7. Sun Shading Horizontal Overhang (sumber google)

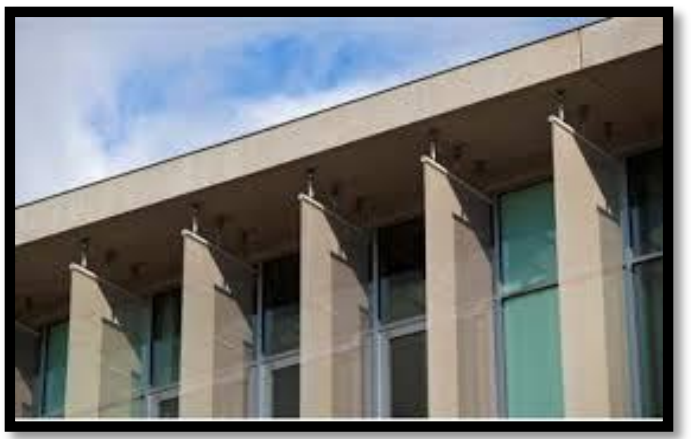

Gambar 8. Sun shading tipe Vertical Fin (sumber google)

\subsection{Simulasi Permodelan Fasade Bangunan}

Model simulasi bangunan dengan menggunakan software merupakan cara yang akurat dan minim resiko dalam menghasilkan desain fasade dan sun shading yang tepat untuk mengatasi glare atau silau, software autodesk ecotect berfungsi sebagai software simulasi orientasi sinar matahari terhadap bangunan yang dijadikan model, dengan input data yang dimasukkan seperti jam tanggal dan bulan, software ini akan memvisualisasikan kondisi yang terjadi pada objek.

\subsection{Google Sketchup sebagai software permodelan}

Peneliti menggunakan software Google Sketchup untuk membuat permodelan bangunan dalam hal ini objek studi bangunan hotel Ibis Trans Studio Mall Bandung, adapun tahapan dalam membuat permodelan 3 Dimensi adalah sebagai berikut : 


\subsection{Langkah-Langkah Dalam Penelitian}

Untuk mendukung keberhasilan penelitian ini peneliti membuat langkah-langkah penelitian yang menyangkut permasalahan fasade bangunan objek studi, adapun langkah-langkah penelitian tersebut adalah sebagai berikut:

1. Mengindentifikasi masalah yang timbul yaitu penyimpangan-penyimpangan dalam suatu perencanaan fasade bangunan, serta dampak dan akibat yang timbul akibat penyimpangan tersebut ke dalam latar belakang penelitian.

2. Maksud dan tujuan dalam penelitian ini untuk menjawab fenomena atau masalah yang timbul serta mencari jalan keluar dalam menyelesaikan fenomena yang timbul sebagai kontribusi dalam perencanaan di masa yang akan datang.

3. Kajian Teoritik adalah langkah yang dilakukan dalam mencari teori yang dapat menjadi dasar dalam analisa untuk menyelesaikan permasalahan serta fenomena yang timbul dalam bidang arsitektur dalam hal ini masalah fasade bangunan sebagai elemen arsitektur dan sinar matahari sebagai sumber energi.

4. Data merupakan yang utama dalam penelitian, validasi data serta dari mana data diperoleh. Dalam penelitian ini terdapat 2 macam data penelitian berdasarkan asal data yaitu data primer dan data sekunder.

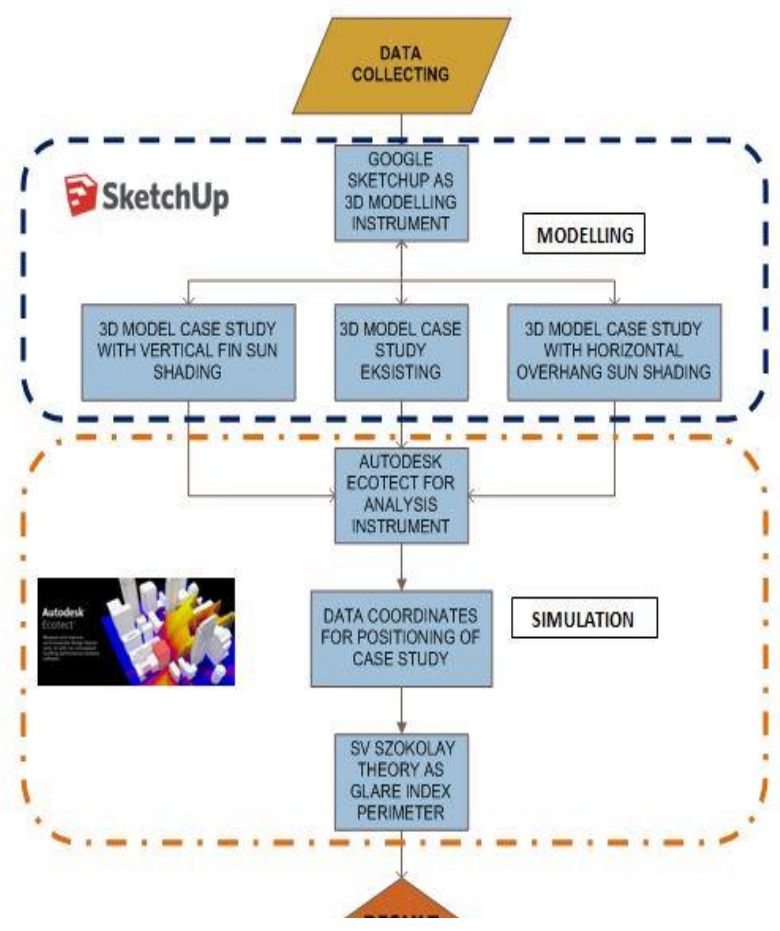

Gambar 12. Diagram metoda kerja analisis data
Data primer merupakan data yang diperoleh langsung dari penelitian, diantaranya adalah :

Karakteristik dari material bidang penutup bangunan yang berupa kaca pada curtain glass yang meliputi data koefisien bahan serta tingkat reflektifitas Bahan.

* Efek glare atau silau yang diprediksi berdasarkan pengukuran tingkat pantulan akibat radiasi matahari disekitar objek penelitian.

Data sekunder merupakan data yang diperoleh dari objek luar penelitian, diantaranya adalah :

Blockplan, Siteplan, tampak serta potongan, dan spesifikasi teknis dari objek penelitian

* Data geografis objek pengamatan mengenai koordinat bangunan, posisi lintang dan bujur

* Berbagai referensi mengenai teori serta data teknis lainnya.

Pengumpulan data dilakukan setelah ditetapkan lokasi serta objek penelitian yang ditentukan berdasarkan kriteria-kriteria yang disyaratkan sebagai objek penelitian, terdapat dua jenis data yang diperlukan dalam penelitian ini yaitu :

Data kepustakaan yaitu data yang bersumber dari berbagai literatur ilmiah, jurnal maupun bahan laporan yang berhubungan dengan materi penelitian baik yang berasal dari lembaga akademis maupun instansi resmi pemerintah serta instansi-instansi lain yang berhubungan dengan materi penelitian.

Data lapangan, yaitu data yang bersumber langsung dari objek penelitian di lapangan baik berupa objek gedung, model material maupun data lingkungan di sekitar objek, teknik observasi, pengukuran, pemotretan dilakukan untuk proses pengambilan data. 


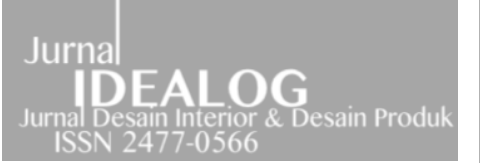

Dari data ini dapat kita jadikan bahan analisa untuk diproses pada tahap berikutnya (Suharsimi dan Ari kunto 1993).

\section{OBJEK STUDI}

Objek Penelitian mengambil lokasi di kota Bandung sebagai kota yang beriklim Tropis lembap di kawasan Trans Studio Mall jalan Jenderal Gatot Subroto No. 289 Bandung Hotel Ibis ini memiliki desain arsitektur yang modern minimalis dengan fasade dinding curtain glass berwarna biru, studi kasus difokuskan terhadap bangunan hotel Ibis Trans Studio Mall yang menghadap Utara-Selatan. bujur timur

Lokasi objek studi pada kawasan garis balik isoterm $6^{\circ} 55$ Lintang Selatan dan $107^{\circ} 38$

\subsection{Posisi Fasade Bangunan}

Fasade bangunan menghadap ke arah Selatan sedangkan bidang kaca Curtain Glass menghadap ke arah jalan Jenderal Gatot Subroto yang berada di arah Timur. Sehingga bila dilihat dari peta google maps yang sudah diproyeksikan dengan autodesk autocad maka akan terlihat bahwa bangunan hotel Ibis menghadap ke arah Selatan dengan sudut bukaan $58^{\circ} \mathrm{ke}$ arah timur, dan $32^{\circ} \mathrm{ke}$ arah Utara. Seperti yang terlihat pada gambar berikut ini.

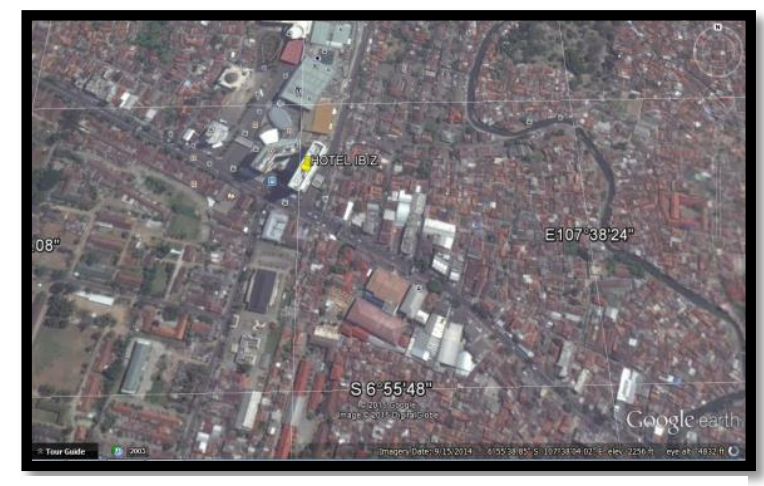

Gambar 13. Peta lokasi Hotel Ibis Trans Studio Mall Bandung

\subsection{Tampak Fasade Bangunan}

Masuknya teori bangunan tinggi yang berasal dari negara beriklim Sub Tropis yang menggunakan Curtain Glass sebagai Building Enclosure, diadopsi secara gamblang di negara kita yang beriklim Tropis lembap, dengan alasan faktor estetika, mudah dalam pemasangan dan perawatan serta menjadi pilihan dari arsitek profesional untuk finishing eksterior.

Sejak berkembangnya industri kaca yang memproduksi komponen dari Curtain Glass untuk Building Enclosure bangunan tinggi, pada tahun 1970 an, maka produk-produk manufaktur kaca banyak menghasilkan produk yang semakin beragam dan semakin baik kualitasnya, namun produk kaca yang direkayasa untuk masalah kenyamanan hanya melihat pada satu sisi aspek saja, yaitu bagian yang berada di dalam bangunan bukan kepada lingkungan sekitar yang terkena dampak dari penggunaan material kaca sebagai komponen dari Curtain Glass.

Fasade eksisting merupakan dinding kaca atau Curtain Glass dengan material Jenis kaca panasap dark blue, tanpa penghalang sinar matahari sehingga sehingga menimbulkan dampak glare atau silau pada bangunan. Garis horizontal yang melintang merupakan ornamen atau penanda tinggi elevasi lantai pada bangunan sehingga dinding kaca tidak terlihat polos.

Gedung bertingkat tinggi pada awal mula perkembangannya merupakan suatu susunan yang melambangkan ekspresi religius dan monumental, tetapi kini secara fisik telah didominasi oleh ungkapan yang menyiratkan ekspresi komersial, ekspresi yang ditampilkan oleh tiap-tiap gedung sangat beragam, perkembangan arsitektur bangunan bertingkat tinggi yang menjamur khususnya di kota-kota besar diartikan dengan the glass box sebagai perlambang modernitas sebuah kota.

Kecenderungan membangun bangunan tinggi yang menggunakan Curtain Glass kaca di kota-kota besar terkonsentrasi pada kawasan pusat-pusat bisnis dan niaga yang disebut 


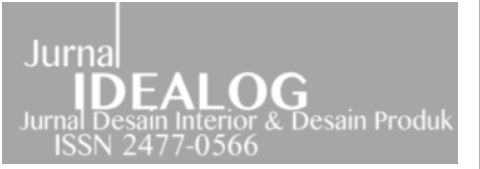

sebagai kawasan CBD (Central Bisnis District) hal ini mulai terlihat dikota Bandung pada awal tahun 2000 ketika Bandung SuperMall dibangun dikawasan jalan Gatot Subroto, serta bergabungnya CT Corp untuk membangun Trans Studio Mall di kawasan tersebut yang menghasilkan tiga bangunan tinggi di kawasan tersebut salah satunya Hotel Ibis.

Untuk menganalisa fasade bangunan Hotel Ibis Trans Studio Mall Bandung peneliti membutuhkan data eksternal seperti denah, tampak bangunan dan 3 dimensi oleh karena itu peneliti membuat permodelan 3d pada software google sketchup.

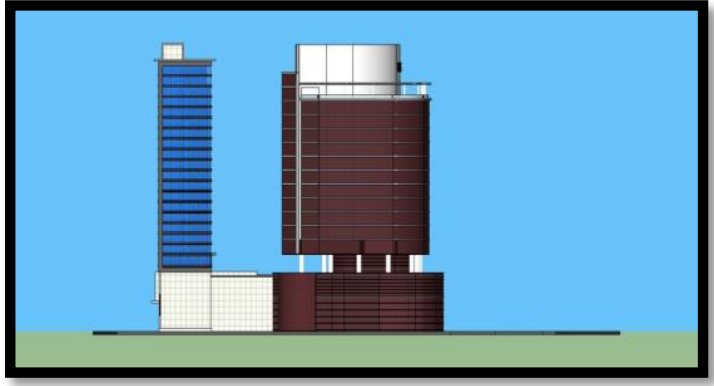

Gambar 14. Posisi Fasade Bangunan dari Arah Utara

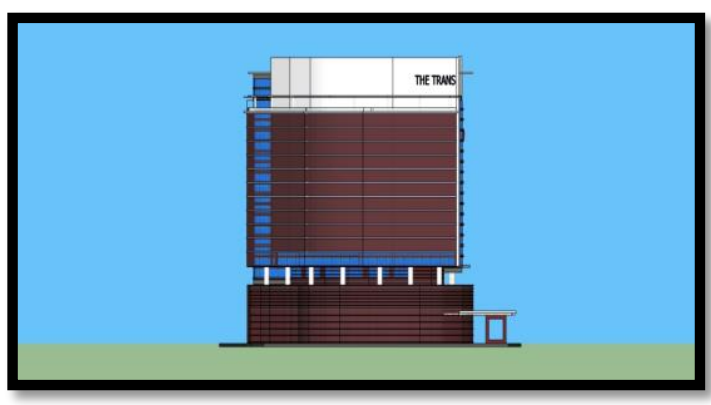

Gambar 16. Posisi Fasade Bangunan dari Arah Barat

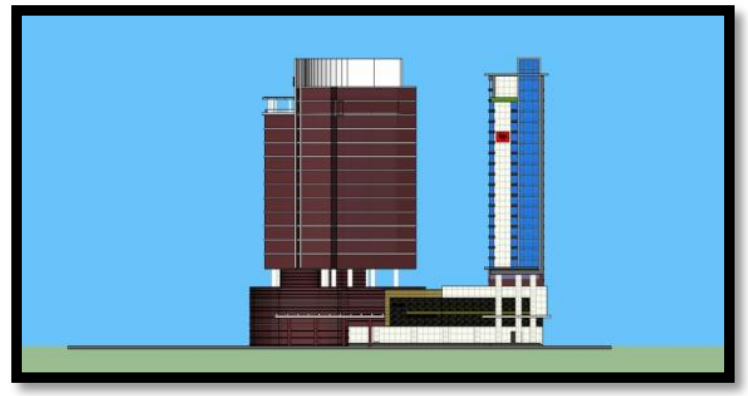

Gambar 15. Posisi Fasade Bangunan dari Arah Selatan

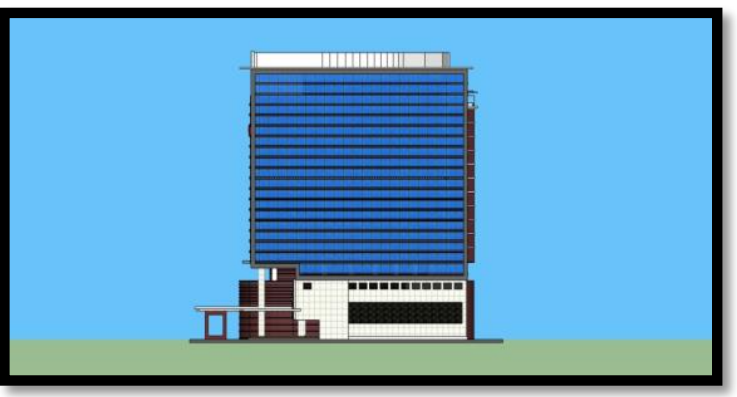

Gambar 17. Posisi Fasade Bangunan dari Arah Timur

\subsection{Jam Pengamatan}

Periode atau observasi penelitian pada bulan Juni pada tanggal 22 dilakukan pengamatan satu hari penuh, karena pada tanggal tersebut cahaya matahari pada posisi tegak lurus terhadap garis lintang Selatan, dan waktu ukur penelitian dilakukan dari jam 06.00 sampai pukul 11.00 dengan interval satu jam. Waktu pengamatan digunakan waktu matahari (Solar Time) untuk kota Bandung yaitu jam 09.08 hal ini dilakukan untuk mengetahui jam berapa intensitas glare atau silau yang paling tinggi.

\subsection{Bulan Pengamatan}

Bulan pengamatan dilakukan pada bulan Juni dimana posisi matahari pada bulan Juni tanggal 22 berada tegak lurus garis lintang Selatan $23^{\circ} 27^{\prime}$ yang merupakan garis balik Capricorn. 

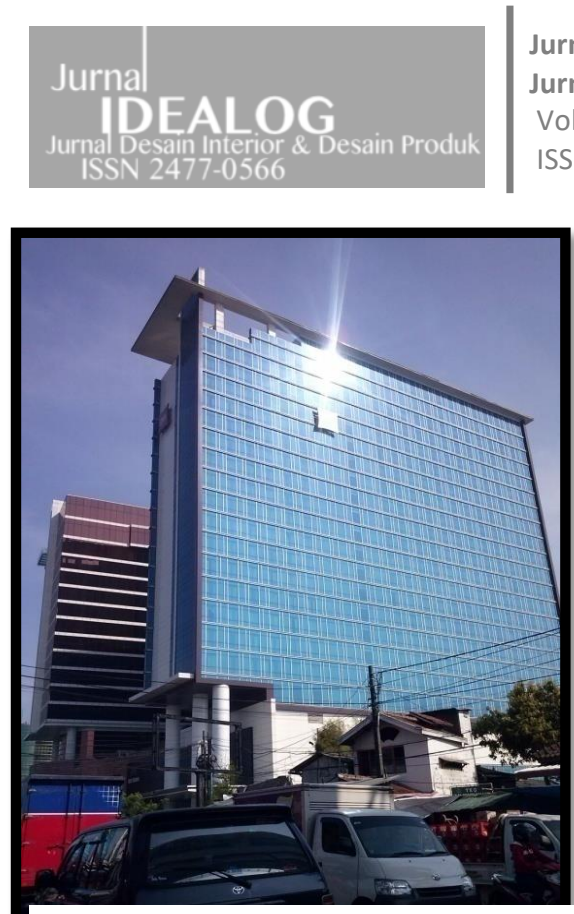

Gambar 18. Hotel Ibis TSM tahun 2015 jam 09.08 wib

\subsection{Jenis Kaca Pada Objek Studi}

Jenis kaca yang digunakan pada Objek Studi adalah kaca yang diproduksi oleh PT. Asahimas Flat Glas Tbk. Dengan tipe Flat glass kode product Panasap jenis material kaca yang digunakan untuk menyerap panas dan sinar matahari. Kaca tersebut dilapisi dengan beberapa unsur logam yang mampu mereduksi panas dan radiasi matahari.

Informasi mengenai sampel material didapatkan dengan cara menanyakan pada bagian Engineering dan Maintenance Building, dari hasil wawancara diperoleh informasi Fasade Curtain Glass pada bangunan hotel Ibis Trans Studio Mall Bandung menggunakan material kaca produksi PT. Asahimas dengan tipe Panasap dengan ketebalan $8 \mathrm{~mm}$ yang berwarna dark blue.

\section{ANALISIS DATA}

\subsection{Fasade Eksisting}

Hasil analisis yang diperoleh dari 3 simulasi permodelan, peneliti menemukan fasade eksisting objek studi menghasilkan potensi glare atau silau yang cukup besar, hal ini bisa dibuktikan dari hasil yang diperoleh dari analisis pada jam 06.00 intensitas glare menunjukan nilai indeks glare 14 dari batas aman indeks glare 22-28, pada jam 07.00 intensitas glare menunjukan nilai indeks glare 14.98 dari batas aman indeks glare 22-28, jam 08.00 intensitas glare atau silau

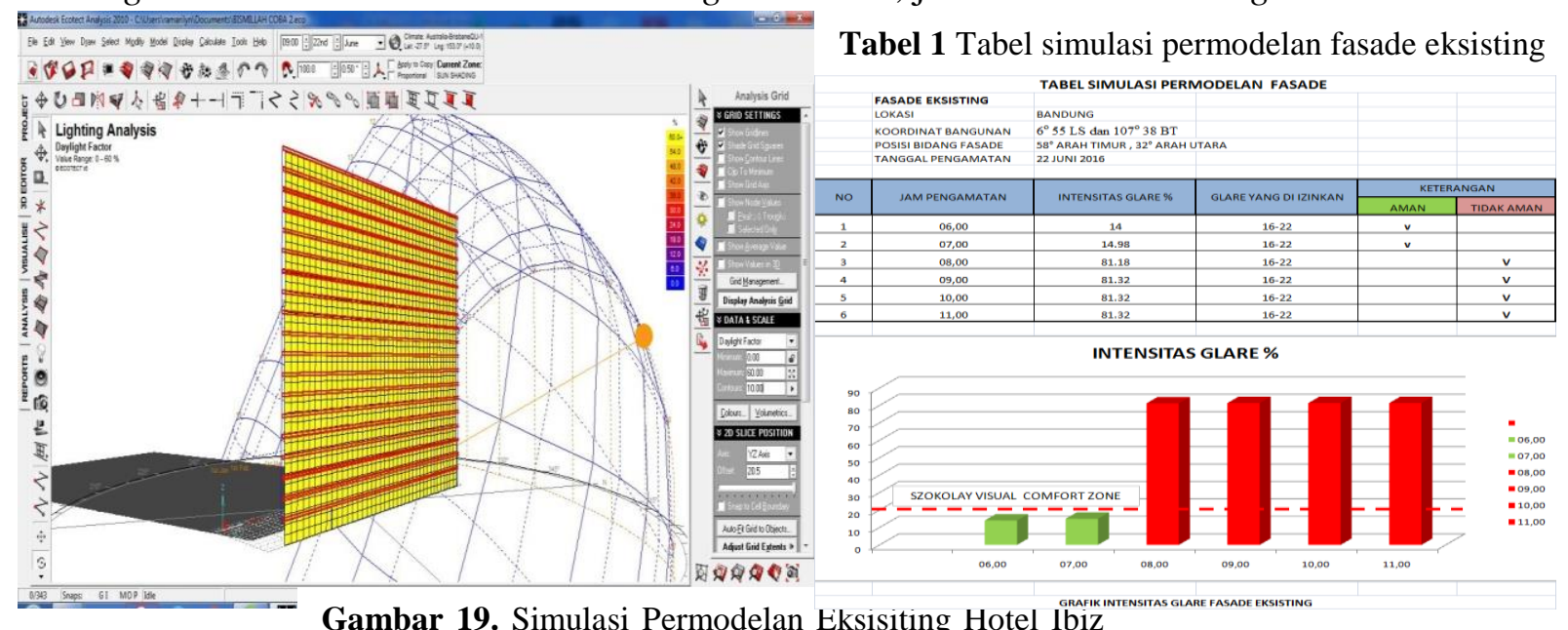

Gambar 19. Simulasi Permodelan Eksisitıng Hotel Ibiz

saat tekena paparan silau /glare

naik secara signifikan menjadi 81.18 melebihi batas aman indeks glare lebih dari 28, jam 09.00 s/d 11.00 indeks glare pada posisi 81.32. Hasil ini membuktikan bahwa kondisi eksisting fasade objek studi tidak mampu untuk mengatasi glare atau silau yang terjadi, sesuai dengan hasil pengamatan langsung saat fenomena tersebut terjadi. 


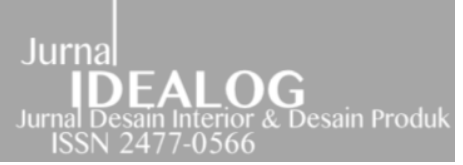

\subsection{Fasade dengan Sun Shading tipe Vertical}

Hasil analisis simulasi permodelan fasade sun shading vertical peneliti menemukan indeks glare atau silau pada jam 06.00 - jam 08.00 menunjukan angka 21.33 dari batas aman indeks glare 22-28 yang diizinkan, jam 09.00-11.00 menunjukan indeks glare di angka 21.99 dari

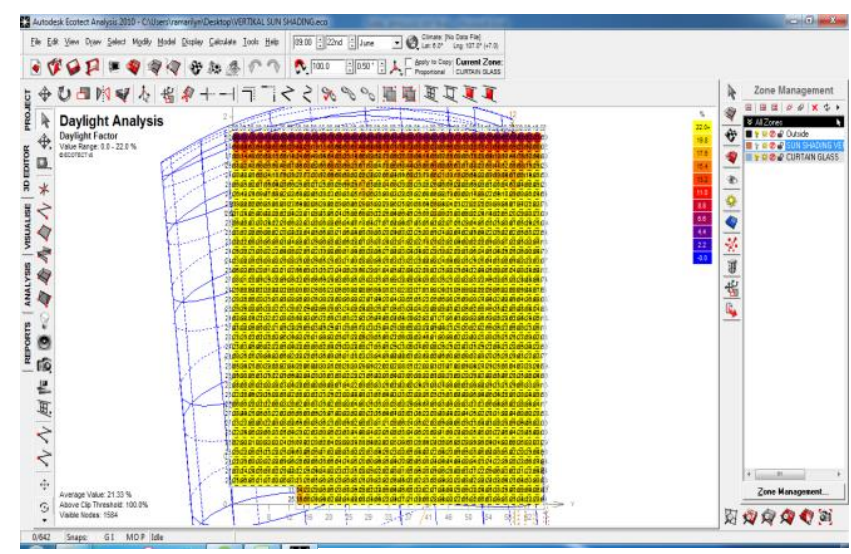

Tabel 2 Tabel dan grafik fasade sun shading vertical
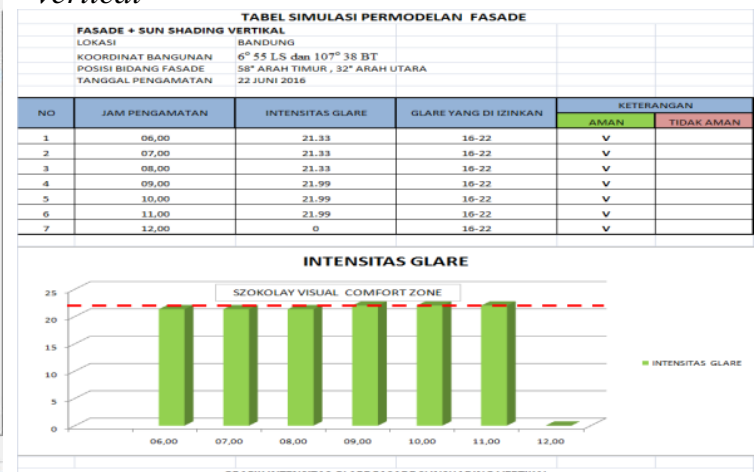

Gambar 20. Simulasi penyinaran pada fasade sun shading

vertical jam 09.00

batas aman yang di izinkan 22-28, hal ini terjadi karena peneliti menggunakan desain sun shading vertical yang sudah di desain pada waktu kritis terjadinya glare yaitu pada jam 09.00, sehingga intensitas glare atau silau yang terjadi pada sunshading vertikal tersebut mendekati batas tidak aman dari faktor glare yang diizinkan.

\subsection{Fasade Sun Shading Horizontal}

Hasil analisis simulasi permodelan fasade sun shading horizontal peneliti menemukan intensitas glare atau silau pada jam $06.00 \mathrm{~s} / \mathrm{d} 11.00$ menunjukan indeks glare pada angka 6.34 sangat aman dari batas indeks glare yang ditentukan yaitu 22-28. Hasil ini membuktikan bahwa fasade sun shading horizontal mampu untuk mengatasi intensitas glare secara maksimal pada objek studi.

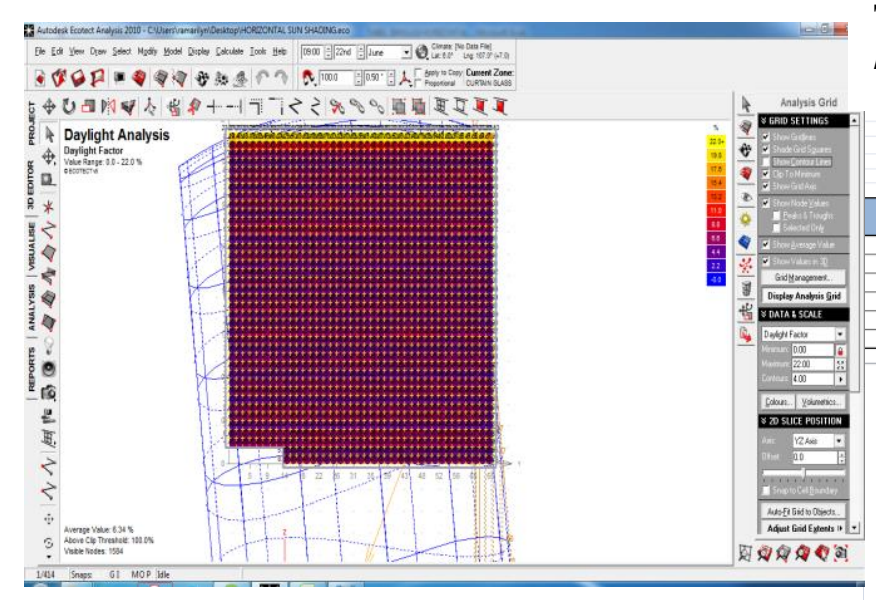

Tabel 3 Tabel dan grafik fasade sun shading horizontal
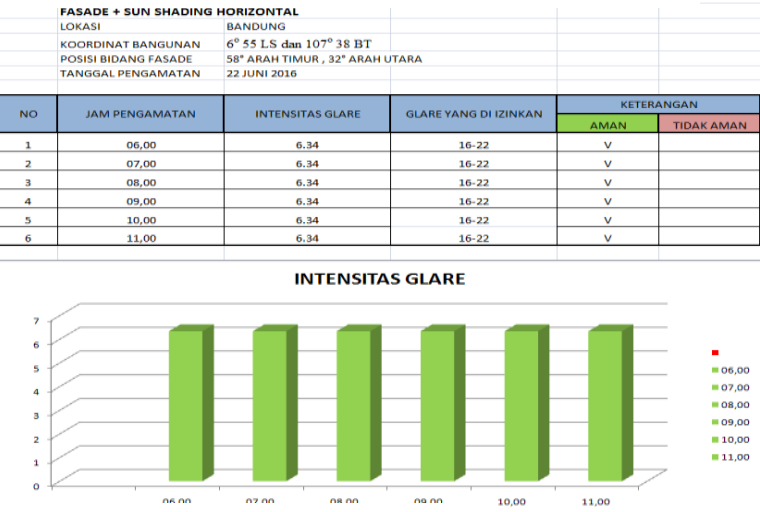

Gambar 21. Simulasi penyinaran pada fasade sun shading horizontal jam 09.00 


\section{KESIMPULAN DAN SARAN}

\subsection{Fasade memakai sun shading horizontal}

Dari hasil analisis permodelan fasade yang memakai horizontal sun shading ditemukan

Tabel 4 Tabel indeks glare dengan kategori tidak terasa.

indeks glare yang paling maksimum pada angka 6.34 pada jam 06.00-11.00, angka tersebut berada dalam kategori tidak terasa dalam indeks glare Szokolay dengan nilai indeks glare 0-10. Jika fasade horizontal sun shading diaplikasikan pada bangunan objek studi, desain fasade akan mempunyai dampak kenyamanan visual pada manusia yang melihat bangunan tersebut.

\begin{tabular}{|l|l|}
\hline $\begin{array}{l}\text { Tingkat } \begin{array}{l}\text { Ketidaknyamanan } \\
\text { Discomfort Level }\end{array} \\
\text { Tidak terasa }\end{array}$ & $\begin{array}{l}\text { Silau } \\
\text { Siau }\end{array}$ \\
\hline Terasa & $0-10$ \\
\hline Dapat Diterima & $10-16$ \\
\hline Tidak Nyaman & $16-22$ \\
\hline $\begin{array}{l}\text { Sangat Tidak } \\
\text { Nyaman }\end{array}$ & Lebih dari 28 \\
\hline
\end{tabular}

\subsection{Saran}

- Disarankan kepada arsitek profesional untuk mempertimbangkan faktor iklim dalam merancang sebuah karya arsitektur, terutama faktor glare atau silau yang akan berdampak pada penampilan fasade bangunan, penggunaan sun shading tipe eksternal dalam mengatasi permasalahan faktor glare atau silau menjadi solusi atas permasalahan tersebut.

- Saran pada objek studi penelitian yaitu hotel Ibis Trans Studio mall Bandung, berdasarkan hasil analisis permodelan sun shading vertical dan horizontal, sebagai pembanding dari kondisi fasade eksisting bangunan, disarankan menggunakan sun shading tipe horizontal dengan jarak antar sun shading tiap $3.00 \mathrm{~m}$ tebal sun shading $15.00 \mathrm{~cm}$, lebar sun shading $86.00 \mathrm{~cm}$ dan panjang $80 \mathrm{~m}$ (berdasarkan hasil analisis peneliti) efektif dalam mengatasi faktor glare atau silau.

- Permasalahan utama yang dialami oleh bangunan objek studi yaitu Glare atau silau bagian eksterior, namun perlu kita ketahui terdapat permasalahan lain yaitu ketidaknyamanan termal dan radiasi pada bagian dalam bangunan, tentunya tesis ini dapat menjadi dasar untuk penelitian lanjutan dalam menyelesaikan masalah tersebut.

\section{Daftar Pustaka}

[1] Koenigsberger, Ingersoll \& Szokolay. 1974 . Manual Of Tropical Housing and Building. London . Longman Group Ltd.

[2] Lippsmeier, Georg. 1994. Bangunan Tropis. Jakarta. Penerbit Erlangga.

[3] Linda Groat \& David Wang, 2002, Architectural Research Methods 2nd Edition, Wiley Publications.

[4] Olgyay, Aladar \& Victor. 1977. Solar Control and Shading Devices, England. The Construction Press LTD.

[5] Olgyay, Victor. 1963, Design With Climate : bioclimatic Approach to Architectural Design, England. The Construction Press LTD.

[6] Szokolay. SV. 1980 . Enviromental Science Book For Architects and Builders, Lancaster. England. The Construction Press LTD.

[7] Appendix Reflected solar Glare Study jurnal, Design Community \& Environment 2009 
[8] A Methods For Estimating Discomfort Glare From Exterior Lighting systems, Jurnal Volume 9 issues 1 April 2011

[9] Wienold, J. and Christoffersen, J., 2006. Evaluation methods and development of a new glare prediction model for daylight environments with the use of CCD cameras. Energy and Buildings, 38(7): 743-757.

[10] Aslam, T. M., Haider, D., \& Murray, I. J. (2007). Principles of disability glare measurement: anophthalmological perspective. Acta Ophthalmologica Scandinavica, 85(4), 354-360.

[11] Wienold, J., 2007. Dynamic Simulation of blind control strategies for visual comfort and energy balance analysis, Building Simulation, Bejing, pp. 1197-1204.

[12] Wienold, J., 2009. Daylight Glare in Offices. (PhD under review), University Karlsruhe

[13] Adryanto Ibnu Wibisono, 1999, Pengaruh Glare Pada Bidang Kaca Bangunan Tinggi Terhadap Lingkungan Studi Kasus Menara Imperium Jl. Hr. Rasuna Said Jakarta Selatan Dan Menara Jamsostek, Jl. Jend. Gatot Subroto Jakarta Selatan, Universitas Diponegoro Semarang.

[14] Gita Larrissa, 2015, Pengaruh Shading Device Terhadap Tingkat Radiasi Sinar Matahari Pada Permukaan Selubung Bangunan Kantor Bertingkat Studi Kasus Wisma Bumiputera Bandung, Universitas Katolik Parahyangan Bandung.

[15] RM. Patiunus, 1997, Pengaruh Existensi Pematahan Sinar Pada Fasade Bangunan Terhadap Efesiensi Pemakaian Beban Energi AC Di Daerah Tropis Lembab Studi Kasus Gedung Kantor Sekwilda Tk.I Jawa Tengah Semarang, Universitas Diponegoro Semarang. 